\section{Alkoxytrimethylammonium Salts and Muscarine}

In connection with natural product studies, we have had occasion to consider the chemical and pharmacological properties of alkoxytrimethylammonium salts.

Methoxytrimethylammoniumiodide, ethoxytrimethylammonium iodide, and propoxytrimethylammonium iodide have been compared in several pharmacological tests with tetramethylammonium iodide, ethyltrimethylammoniumiodide, and propyltrimethylammonium iodide. The results are tabulated below. In general the alkoxy and alkyl trimethylammonium salts appear very similar in biological properties, manifesting typical cholinergic activity (Table).

Methoxytrimethylammonium iodide ${ }^{1}$ causes an effect on the carotid pressure of chloralosed dogs similar to that of tetramethylammonium iodide (IV), the activity ratios between $I$ and IV being $1: 1 \cdot 5$ and $1: 3$, depending upon the experimental conditions.

As the molecular weight of compounds in the above series increases, a change in the pharmacological action is observed from a hypertension of the nicotine type to a muscarine-like hypotension. This effect takes place more rapidly and the muscarinic properties are more intense in the alkoxyquaternary derivatives. At a dose of $0.1 \mathrm{mg} / \mathrm{kg}$ i.v., propyltrimethylammonium iodide (VI) and to a somewhat greater extent propoxytrimethylammonium iodide (III) are hypotensive in the normal dog; atropine changes the blood pressure to a moderate hypertension.

Furthermore the two series had similar properties as determined by treatment of preparations of isolated intestinal strip of rabbit, of the muscle Rectus abdominis of the toad and of a neuromuscular preparation of the toad, as well as toxicity tests on mice and rabbits.

It is interesting that the alkoxytrimethylammonium salts resemble muscarine, not only in pharmacological properties, but in certain chemical properties as well. KöGL ${ }^{\star}$ has suggested alternative structures for the alkaloid:

\section{$\mathrm{C}_{2} \mathrm{H}_{5} \mathrm{CHOHCHCHO}$ $\mathrm{N}\left(\mathrm{CH}_{3}\right)_{\mathrm{B}}^{+} \mathrm{X}^{-}$ \\ $\mathrm{C}_{2} \mathrm{H}_{5} \mathrm{CHCHOHCHO}$ $\mathrm{N}\left(\mathrm{CH}_{3}\right)_{8}^{+} X^{-}$}

1 F. Kögl, H. Duisberg, and H. Erxleben, Ann. Chem. 486 , $156(1931)$ but synthetic products with these structures, although possibly incorrect configurations, have no appreciable muscarinic activity. It may be significant that an alkoxytrimethylammonium salt contains a potential aldehyde group. MEISENHEIMER ${ }^{2}$ has shown that compounds of the structure $R \mathrm{CH}_{2} \mathrm{ON}\left(\mathrm{CH}_{3}\right)_{3} X$ are decomposed by alkali to trimethylamine and the corresponding aldehyde $(R C H O)$. This reaction resembles the degradation of muscarine by silver oxide to trimethylamine and $\alpha, \beta$-dihydroxyvaleric acid, as silver oxide would oxidize an intermediate aldehyde. The ScHiff and ANGELI-RIMINI aldehyde reactions obtained with muscarine may also be explained by an alkoxy-quaternary structure.

As alkali is employed in the ANGELI-RImini test, alkoxyquaternaries should function as aldehydes. ScHIF tests on methoxy and ethoxytrimethylammonium iodides are negative in the cold, but positive on heating for one minute at $80^{\circ}$, conditions in which a control is negative; the closely-related trimethylamineoxide hydrochloride gives a positive test at room temperature.

One observation concerning the aldehyde function of muscarine is better understood in terms of a potential than a free aldehyde group. This is the failure of attempts to reduce muscarine with hydrogen and platinum catalyst.

It appears worthwhile to examine more alkoxyquaternaries, especially amyloxy and oxygenated amyloxy compounds, assuming a relation to muscarine. The method used for the preparation of the methoxy, ethoxy and propoxytrimethylammonium iodides, reaction of trimethylamineoxide with alkyl iodide ${ }^{2}$ gives a complex mixture of products which cannot be satisfactorily separated when butyl iodide is used. Other synthetic methods will be studied.
E. F. Rogers, D. Bovet,
V. G. Longo, and
G. B. Martni-Bettolo

Laboratory for Therapeutic Chemistry, Istituto superiore di Sanità, Rome, February 25, 1953.

\section{Zusammenfassung}

Es wird die azetylcholinähnliche Wirkung der Alkoxytrimethylammoniumsalze aufgezeigt und im Vergleich zur Struktur der natürlichen Muskarine diskutiert.

1 F. Kögl and H. Veldstra, Ann. Chem. 552,1 (1942).

2 J. Meisenheimer, Ann. Chem. 397,273 (1913).

\begin{tabular}{|c|c|c|c|c|c|c|c|c|}
\hline & \multirow{2}{*}{ Substance } & \multirow{2}{*}{ m.p. } & \multicolumn{2}{|c|}{ Blood pressure in chloralosed dog 1} & \multirow{2}{*}{$\begin{array}{c}\text { Toad } \\
\text { Rectus } \\
\text { abdominis }\end{array}$} & \multirow{2}{*}{$\begin{array}{l}\text { Rabbit } \\
\text { isolated } \\
\text { intestine }\end{array}$} & \multirow{2}{*}{$\begin{array}{l}\text { Mouse } \\
\text { L.D. } \\
\text { i.v. } 50\end{array}$} & \multirow{2}{*}{$\begin{array}{l}\text { Rabbit } \\
\text { L.D. } 50 \\
\text { i.v. } 50\end{array}$} \\
\hline & & & Normal ${ }^{2}$ & Atropinized ${ }^{3}$ & & & & \\
\hline I. & $\mathrm{MeONMe}^{3} \mathrm{I}^{6}$ & $161^{\circ}$ & Hypertension $(0.075-0.15)$ & Hypertension & 20 & 2 & 25 & 7 \\
\hline & EtONMe ${ }^{3}{ }^{7}$ & $122^{\circ}$ & $\begin{array}{l}\text { Hypotension followed by } \\
\text { hypertension }\end{array}$ & Hypertension & 15 & $\overline{4}$ & 40 & 5 \\
\hline III. & PrONMe $^{31}{ }^{8}$ & $125^{\circ}-138^{\circ}$ & Hypotension & Slight hypertension & $2 \cdot 5$ & 2 & 50 & 3 \\
\hline IV. & $\mathrm{MeNMe}^{3} \mathrm{I}$ & $230^{\circ}$ & Hypertension $(0.05)$ & Hypertension & $2 \cdot 5$ & 1 & 10 & 3 \\
\hline & $\mathrm{EtNMe}^{3} \mathrm{I}$ & sub & Hypertension $(0.1-0.2)$ & Hypertension & 10 & $1 \cdot 5-2$ & 15 & 5 \\
\hline VI. & $\operatorname{PrNMe}^{3} \mathrm{I}$ & $188^{\circ}$ & Hypotension & Slight hypertension & 50 & 20 & 80 & 7 \\
\hline
\end{tabular}

1 I.v. injection.

2 The data in the brackets represent the dose in $\mathrm{mg} / \mathrm{kg}$ causing a blood pressure rise of 80-100 $\mathrm{mm} \mathrm{Hg}$. All doses are expressed in reight of free base.

3 Atropine, $2 \mathrm{mg} / \mathrm{kg}$ i.v.

4 Contraction compared with that of acetylcholine $(0.5 \mathrm{mg} / \mathrm{l})$, isolated muscle, Ringer solution, doses in mg/l.

5 Contraction of isolated intestine strip compared with that of tetramethylammonium iodide $(1 \mathrm{mg} / \mathrm{l})$, Tyrode solution, doses in $\mathrm{mg} / \mathrm{l}$.

$61 \%$ : Calc., 58.57 ; found, 58.52

$71 \%$ : Calc., 54.92 ; found, $55 \cdot 10$

$81 \%$ : Calc., 51.78; found, 51.86. The melting point of the compound is erratic $\left(125-138^{\circ}\right)$ and is lower than the reported value of $145^{\circ}$. However the purity of this sample and the other quaternaries was checked by paper chromatography. 